Bird diversity and land use on the slopes of Mt. Kilimanjaro and the adjacent plains, Tanzania

Eija Soini 



\section{Bird diversity and land use on the slopes of Mt. Kilimanjaro and the adjacent plains, Tanzania}




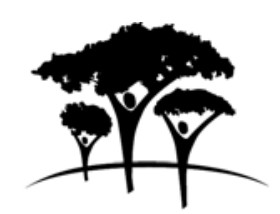

World Agroforestry Centre

TRANSFORMING LIVES AND LANDSCAPES

Correct citation: Soini E. 2006. Bird diversity and land use on the slopes of Mt. Kilimanjaro and the adjacent plains, Tanzania. ICRAF Working Paper no. 11. Nairobi, Kenya: World Agroforestry Centre.

Titles in the Working Paper Series aim to disseminate interim results on agroforestry research and practices and stimulate feedback from the scientific community. Other publication series from the World

Agroforestry Centre include: Agroforestry Perspectives, Technical Manuals and Occasional Papers.

Published by the World Agroforestry Centre

United Nations Avenue

PO Box 30677, GPO 00100

Nairobi, Kenya

Tel: +254(0)20 7224000, via USA +1 6508336645

Fax: +254(0)20 7224001, via USA +1 6508336646

Email: icraf@cgiar.org

Internet: www.worldagroforestry.org

(C) World Agroforestry Centre 2006

ICRAF Working Paper no. 11

The views expressed in this publication are those of the author(s) and not necessarily those of the World Agroforestry Centre.

Articles appearing in this publication may be quoted or reproduced without charge, provided the source is acknowledged. No use of this publication may be made for resale or other commercial purposes.

All images remain the sole property of their source and may not be used for any purpose without written permission of the source. 


\section{About the author}

Eija Soini has a Masters degree in Development Geography from the University of Helsinki, Finland. She has also studied a range of other subjects including Biology, African studies, Cultural Anthropology, Education, and Remote Sensing and GIS. Her research has concentrated on land use/land use change and sustainable livelihoods, ecologic implications of land use change, land cover monitoring system methodology development, and digital map production. She is currently compiling an article $\mathrm{PhD}$ thesis "Socio-economic and ecological dynamics of land use change in the highlands of East Africa". She has work experience from both private and non-profit (World Agroforestry Centre, NGOs) sectors. 


\section{Abstract}

This study of bird distribution in the main land use categories of the slopes of Mt Kilimanjaro, Tanzania, aims at understanding potential impacts of the land use changes on birds. A land use map of the study area was derived from a Landsat image, and land use change information came from an earlier study by the author. Bird data were collected by observations along timed, standardised walks. The Shannon-Weaver indices of bird diversity for highlands, bushland and lowlands were 3.29, 2.99, and 2.62 respectively. The highland category was divided into two, homegarden and highland garden, as bird populations were distinct. Highland garden had the highest diversity (3.15). Homegarden ranked second most diverse (3.07). The lower species diversity and number of individuals in homegardens was probably due to the lower niche diversity and human disturbance. Lowland fields had low diversity index as they are dominated by large flocks of birds. Each land use type had a considerable number of species that were not seen in the others. As bushland is disappearing, the species currently threatened are the fifteen bushland species that are not found in other land use types. Growing population pressure leading to de-agrarianisation of the homegarden area is likely to affect homegarden bird populations, though it is not clear whether the very high human population density will prevent it from supporting a highland garden type of a bird population.

\section{Keywords}

avian diversity, similarity, land use change 


\section{Acknowledgements}

This study was done in conjunction with a World Agroforestry Centre project "Socio-ecologic dynamics of land use change on the southern slopes of Mt. Kilimanjaro, Tanzania". It was made possible by an APO (Associate Programme Officer) programme at the World Agroforestry Centre (ICRAF) funded by the Ministry for Foreign Affairs, Department of Development Policy in Finland. The author wishes to thank Richard Coe of the World Agroforestry Centre for assisting with some of the data analysis, giving valuable feedback and suggestions on the content, and editing my English style; Matti Nummelin from the Finnish Ministry for Foreign Affairs, Department of Development Policy for his useful comments; Peter Oliver from Marangu for resident birder's useful feedback on the bird list; and A. Kessy from Kilimanjaro LandCare and Ecological Management Association (KILEA) for collaboration during my work in Kilimanjaro, and specifically for helping me with his extensive knowledge on trees. 


\section{Contents}

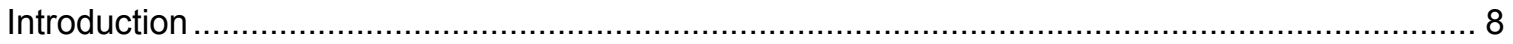

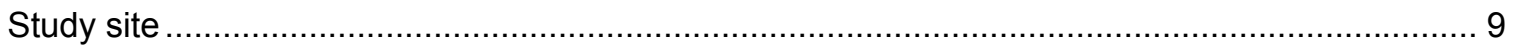

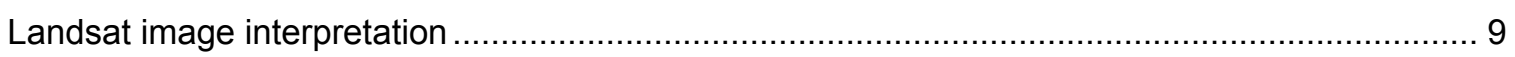

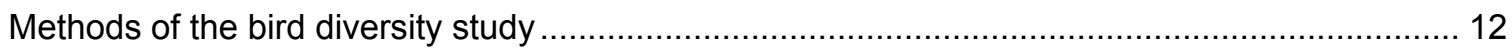

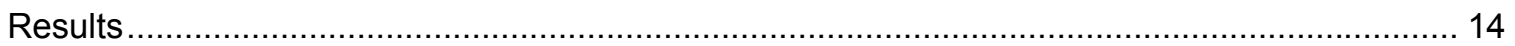

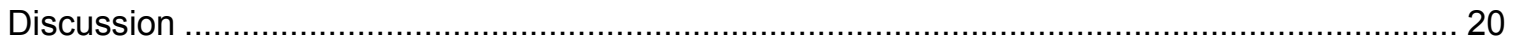

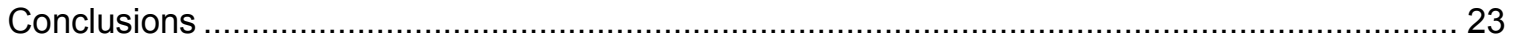

Appendix

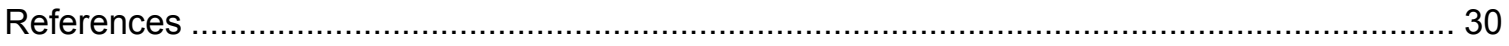




\section{List of tables}

Table 1. Land use/cover classes as detected from a Landsat image by Fuzzy C Mean auto-classification. Numbers are percentages of ground-truth points (total of 56 points) at which each land cover component was found.

Table 2. Comparing bird diversity and species and individual numbers in three habitat types on the southeastern slopes of Mt. Kilimanjaro and the adjacent plains

\section{List of figures}

Figure 1. The study area on the southern slopes of Mt. Kilimanjaro in Tanzania. Land use map derived from Landsat +ETM image of February 2000.

Figure 2. Species accumulation curves for birds in the lowlands $(+)$, bushland $(O)$ and highlands $(\triangle)$ on the south-eastern slopes of Mt. Kilimanjaro. (a) Walk-based curves, (b) Individual-based curves.

Figure 3. Bird species rank abundance in the lowlands, bushland and highlands on the south-eastern slopes of Mt. Kilimanjaro.

Figure 4. Ordination of bird species using a canonical principle coordinates analysis. Species $(O)$ and walks $(+)$ are plotted on the first two principle axes. Points for walks are connected to the centroid of the observations for that land use (L: lowland, B: bushland, H: highland) and season (S: May-July, W: November). Species most characteristic of each land use are labelled 1: Chestnut Weaver, 2: Wattled Starling, 3: Grosbeak Weaver, 4: Red-billed Quelea, 5: Longtailed Fiscal, 6: Speckled Mousebird, 7: Common Bulbul, 8: Trilling Cisticola, 9: Pied Crow, 10: Yellow-rumped Seedeater, 11: Variable Sunbird, 12: Black-and-white Mannikin, 13: Baglafecht Weaver, 14: White-eyed Slaty Flycatcher, 15: African Mourning Dove, 16: Whitebrowed Sparrow-Weaver, 17: Cinnamon-breasted Rock Bunting, 18: Grey Wren-Warbler, 19:

Blue-naped Mousebird, 20: Red-eyed Dove. 


\section{Introduction}

The southern slopes of Mt. Kilmanjaro, Tanzania, have gone through a dramatic change in land use over the past decades. The slopes below the forest reserve boundary at about $1800 \mathrm{~m}$ are now dominated by agriculture. Land use systems vary with altitude, from an intensive tree dominated homegarden system adjacent to the forest down to extensive fields on the lowland plains at about $700 \mathrm{~m}$. Interspersed with this are remnant bushland areas.

Population growth in the area has been dramatic since the beginning of the 20th century. This has had its impact on the landscapes. Soini (2005 b) used aerial photographs from 1961, 1982 and 2000 to show that the main changes were the gradual disappearance of natural bushland vegetation and the expansion of cultivated land. In the early 1960s bushland, (mainly Anderson's, 1982, categories of wooded grasslands, bushed grasslands and bushlands) covered $40 \%$ of the whole study area. By 2000 remaining bushland was just $7 \%$ of the area. Increasing exploitation of the remaining bushland for grazing, firewood collection and volcanic brick cutting, associated with the increased population of the lowlands, is also changing the nature of the habitat. Most of the bushland looks overgrazed and large trees have been cut down. Bushlands have become very fragmented and are now found mainly on the tops of isolated steep volcanic hills. The mean patch size of bushlands in the study area has decreased from 119.4 ha in 1961 to 35 ha in 2000. The core bushland area, calculated with a $50 \mathrm{~m}$ buffer, has decreased from 4238.6 ha in 1961 to a mere 680.1 ha in 2000.

Homegardens, the tree dominated highland farming system, have not extended to lower altitudes since 1961, but the area has gone through significant internal change. Homegardens have become increasingly fragmented due to sub-division of farms among sons. The number of trees has decreased as more land is needed for houses, yards and vegetable gardens. The area is now more densely populated than many areas categorised as urban. Population density in the highlands $(1200-1800 \mathrm{~m})$ is about 650 persons per sq $\mathrm{km}$ (Moshi Rural District Council, pers. comm.).

The lowlands have only recently been used for cropping and permanent habitation, previously being considered either too dry or with high incidence of malaria. Lowlands now have approximately 250 persons per sq $\mathrm{km}$, but the population tends to be clustered in settlements leaving bush and agricultural areas with much lower human densities.

Land use change is known to be a key driver of biodiversity change (Sala et al. 2000). This study comparing bird distribution in the main land use categories of the study area aims at understanding 
potential impacts of the land use changes on birds. As avian communities have been found to function as indicators of overall biodiversity and environmental decline or recovery (e.g. Nohr \& Jorgensen 1997; Canterbury et al. 2000; Chase et al. 2000), bird distribution should give an indication of the general biodiversity levels of the main land use categories of the study area.

\section{Study site}

The study area is situated on the south-eastern slopes and adjacent plains of Mt. Kilimanjaro, the highest $(5895 \mathrm{~m})$ mountain in Africa, in northern Tanzania ( $3^{\circ} 4^{\prime} \mathrm{S}$ latitude and $37^{\circ} 22^{\prime} \mathrm{E}$ longitude) (Fig. 1). Three distinct altitudinal agro-ecological zones can be identified: 1) A lowlands zone of extensive livestock farming and open crop fields, with remnant bushland patches 2) A midlands maize-bean belt which is a mosaic of homegardens and open fields, with few bushland patches interspersed between, and 3) A highland homegarden area dominated by coffee and banana, with many large trees. Lowlands extend up to about $900 \mathrm{~m}$, midlands up to $1200 \mathrm{~m}$ and homegarden area to about $1800 \mathrm{~m}$ above sea level, up to the lower forest boundary. Annual rainfall varies according to the altitude, being $400-900 \mathrm{~mm}$ in the lowlands, 1000 $1200 \mathrm{~mm}$ in the midlands and 1200-2000 mm in the homegarden area (Moshi Rural District Council, pers. comm.; Zongolo et al. 2000). The study focused on lowlands and homegarden areas as this is where most change has been detected.

There is a considerable difference in human disturbance level between homegardens, bushlands and lowlands. The homegarden area is a very disturbed habitat throughout the year, bushlands are to some extent disturbed by firewood collection and grazing all around the year. The level of disturbance in lowlands depends on the cultivation activities taking place in the fields. This study took place at times when there was little human activity in the lowland fields.

\section{Landsat image interpretation}

Land use information used in this survey is based on Landsat +ETM satellite image interpretation (Fig. 1) and Anderson's (1982) vegetation survey. Land use change information is based on study of aerial photographs from 1961, 1982 and 2000 (Soini, 2005 b). The Landsat image was taken on the 17th February 2000, only one day after the aerial photos of the year 2000. Land use information from the Landsat image was used here as it is more detailed and objective than visual interpretation of the aerial photos. 


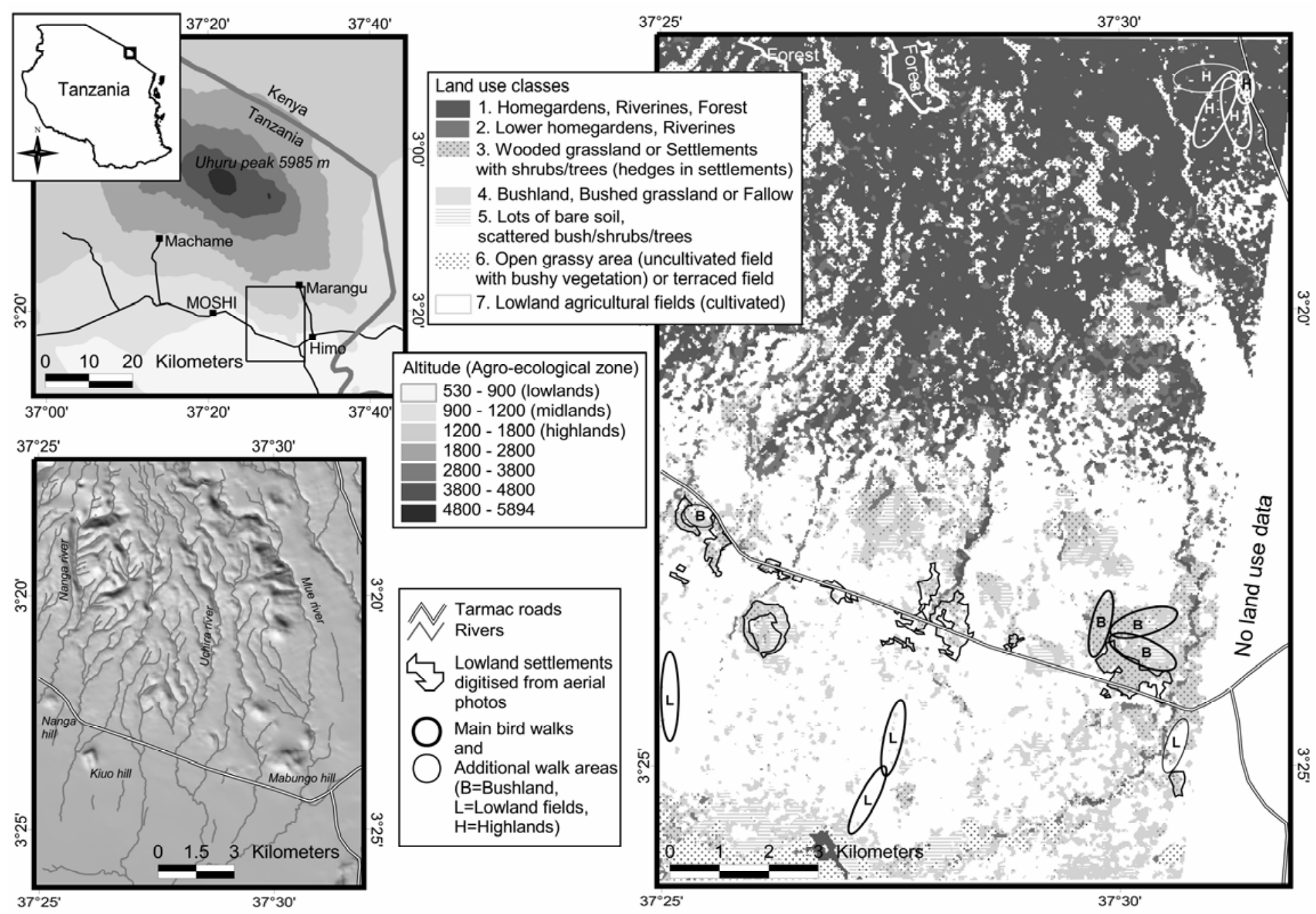

Figure 1. The study area on the southern slopes of Mt. Kilimanjaro in Tanzania. Land use map derived from Landsat +ETM image of February 2000. 
The image was auto-classified by the Fuzzy C Mean algorithm (TNTmips 6.4 manual 2000). This was the only method out of a number tested (including Simple One-Pass Clustering, K Means, Minimum Distribution Angle, ISODATA, Self Organisation and Adaptive resonance) that could satisfactorily distinguish between bushland and lowland agricultural land.

Landsat (ETM) bands 2, 3, 4, 5, 6h and 7 were used in the classification. The original number of classes was fifteen and the maximum iteration time ten. Seven land use categories were left in the final interpretation. The initial merging was done based on accumulated knowledge of the area due to extensive fieldwork, landscape photographs and aerial photographs. Three by three $(3 \times 3)$ pixel majority filter was later applied to the classification. Ground-truthing was conducted in mid-February 2002. This was done by selecting 56 control points, 8 points from each of the categories except the tiny forest patches in the upper part of the study area and the lowland fields. Tracking analyst with the real time Global Positioning System (GPS) was used to navigate to the control points. NDVI image was the best reference for defining the forest boundary even though using NDVI in the auto-classification did not make the forest differ from the adjacent homegardens. Percentages of ground-truth points (total of 56 points) at which each land cover component (dense bush, scattered bush, grassy ground etc.) was found were used in defining the class descriptions (Table 1). In addition, photographs taken from known points (other than the ground-truthing points), and the aerial photos were used as additional information in finding the right class descriptions.

Anderson's (1982) vegetation classification of the region still remains the most comprehensive, but original vegetation types are hard to find. All the land use classes in the study area are, in one way or another, modified by human activities. Class 3 (Table 1) is close to Anderson's Wooded grassland with Acacia and Combretum, though in places trees are wide apart due to the continuous utilisation of the area by humans and livestock. Settlements (or scattered homesteads) consisting of small houses that are easily seen in the aerial photos cannot be distinguished as a class of their own in a Landsat image. Grass roofs and mud or stone walls have the same reflectance as surrounding areas. Widely scattered small iron/zinc roofs do not make enough change to the reflectance of the Landsat image bands to be able to distinguishing settlements from the other classes. Aerial photos were used to define settlement areas for Figure 1. Class 4 is mostly a remnant of Anderson's Bushed grassland or Bushland. In places Commiphora can be found with Acacia. Class 5 represents areas with lots of bare soil exposed, and includes the brick cutting sites on some of the volcanic conical hills. Class 6 can be a fallow/uncultivated field which some bushy vegetation has taken over. In the text all the four different classes of non-cultivated land in the lowlands are simply referred to as bushland. 
Table 1. Land use/cover classes as detected from a Landsat image by Fuzzy C Mean autoclassification. Numbers are percentages of ground-truth points (total of 56 points) at which each land cover component was found

\begin{tabular}{|c|c|c|c|c|c|c|c|c|c|}
\hline Land use class & $\begin{array}{l}\text { Coffee- } \\
\text { banana } \\
\text { farm }\end{array}$ & $\begin{array}{l}\text { Big trees } \\
\text { close } \\
\text { together }\end{array}$ & $\begin{array}{c}\text { Scattered } \\
\text { trees/ } \\
\text { shrubs } \\
\end{array}$ & $\begin{array}{c}\text { Dense } \\
\text { bush }\end{array}$ & $\begin{array}{c}\text { Scattered } \\
\text { bush }\end{array}$ & Bare soil & Stony & Grass cover & $\begin{array}{l}\text { Home- } \\
\text { steads }\end{array}$ \\
\hline $\begin{array}{l}\text { 1. Homegardens, } \\
\text { Riverines, Forest }^{1}\end{array}$ & 100 & & & & & & & & \\
\hline $\begin{array}{l}\text { 2. Lower } \\
\text { homegardens, } \\
\text { Riverines }\end{array}$ & & 75 & 37.5 & & & & & 25 & 37.5 \\
\hline $\begin{array}{l}\text { 3. Wooded grassland } \\
\text { or Settlements with } \\
\text { shrubs/trees (hedges } \\
\text { in settlements) }\end{array}$ & & & 100 & & 25 & 75 & 12.5 & & 87.5 \\
\hline $\begin{array}{l}\text { 4. Bushland, Grasslan } \\
\text { or Fallow }\end{array}$ & & & 50 & 12.5 & 37.5 & 25 & 43.8 & 56.3 & \\
\hline $\begin{array}{l}\text { 5. Lots of bare soil, } \\
\text { scattered } \\
\text { bush/shrubs/trees }\end{array}$ & & & 37.5 & & 37.5 & 87.5 & 12.5 & & 12.5 \\
\hline $\begin{array}{l}\text { 6. Open grassy area o } \\
\text { terraced field }\end{array}$ & & & 62.5 & & & & & 87.5 & \\
\hline $\begin{array}{l}\text { 7. Lowland agricultural } \\
\text { fields (cultivated) }\end{array}$ & & & & ass nc & tgroun & d t truth & & & \\
\hline
\end{tabular}

\section{Methods of the bird diversity study}

Timed walks were used, two hours in the evening, three hours in the morning. In the evening, the walk was one hour in one direction (c. $1.5 \mathrm{~km}$ ), returning the same way. In the mornings another walk was added to another direction from the starting point, half an hour to one direction returning the same route. All birds within about $30 \mathrm{~m}$ distance from a predefined route were recorded. The aim was to walk along straight transects, but due to the terrain and obstructions this was not always possible. In the homegarden area footpaths were used. Three main walk routes were selected in each of the three main land use categories. Highlands were sampled by two routes in the homegarden area and one route in the highland garden area. Each main category had one additional walk done in another location.

Three main bushland routes were on Mabungo hill (840-1000 $\mathrm{m}$ ) and the adjacent area (820-840 $\mathrm{m})$ to the west. Mabungo area was selected simply due to the fact that it is the biggest single area of bushland in the study area and has enough uninterrupted bushland to accommodate a bird transect. Two routes were on Mabungo hill, the other main walk below the hill reached all the way to a small stream to the west of the 
hill. One additional walk was done in the evening on Nanga hill $(830-900 \mathrm{~m})$. This area is a very small patch of bushland in the middle of agricultural fields. Bushland walks were done in the middle of uninhabited patches, but there were schools and homesteads immediately adjacent to the walk areas.

Lowland walks $(700-750 \mathrm{~m})$ crossed open agricultural land where maize (Zea mays), millet (Eleusine coracana), beans (Phaseolus vulgaris) and sunflower (Helianthus annuus) were grown. There are some scattered trees on these open fields. The most common tree species in the lowlands is Faidherbia albida. Other typical farm trees include Azadirachta indica, Cassia siamea, Euphorbia tirucalli, Senna siamea, Leucaena leucocephala, Mangifera indica (Soini 2005 a). One lowland walk was done east of Mue river (760-770 m).

The sample area in the highlands consisted of both traditional Chagga homegardens and a European type garden (highland garden) (1300-1340 m). Homegardens immediately surrounded the highland garden. Both of the highland areas were close to a river. Homegardens are a traditional agroforestry farming system in which coffee (Coffea arabica) and banana (Musa spp.) are the main crops. Many other food crops are grown and plenty of trees are integrated in the system. The most conspicuous trees and/or useful species for the farmers include Albizia spp., Cordia holstii, Croton macrostachys, Grevillea robusta and Rauvolfia caffra (Soini 2005 a; A. Kessy pers. comm.). Sometimes flowers are grown for decoration close to the house. The highland garden has a lot of open space covered by grass, scattered trees of many species, both indigenous and exotic, flowerbeds, and a hedge partly around. An old vegetable garden was part of the highland garden survey area.

Walking pace was adjusted to make the length of all the walks approximately the same. Identification was visual except in some rare cases when voice was used if the bird could not be seen. Bird field guides by Van Perlo (1995), Zimmerman et al. (1999) and Stevenson \& Fanshawe (2002) were used in identification. Nomenclature follows Stevenson \& Fanshawe (2002) which is based on the official East African list edited by Britton (1980) and updated in 1996.

The first part of the bird survey was conducted in the cool dry season, between late May and July in 2001 . The second part was done during the shorter rainy season, in November 2002. This was done to capture variation due to the presence and absence of migratory species and dry-rainy season variation. Six morning records and six evening records were collected from each land use category, eight records from May-July, four from November.

Diversity was measured by species number and Shannon-Weaver's index (H) (Shannon -Weaver 1949). This takes into account evenness as well as number of species. It is estimated as 
$\mathrm{H}=-\sum(\mathrm{Piln}(\mathrm{Pi})$

where $\mathrm{Pi}$ is a proportion of the total number of birds belonging to species $\mathrm{i}$ and $\ln (\mathrm{Pi})$ is the natural logarithm of that proportion, and summation is over all species.

Similarity between land use categories was measured with the Similarity Index (SI) (Odum 1971),

$\mathrm{SI}=2 * \mathrm{C} /(\mathrm{A}+\mathrm{B})$

in which $\mathrm{C}$ is the number of species common to both land use categories, $\mathrm{A}$ is number of species in one land use category, B is number of species in another land use category.

Further analyses used each walk as a sample. Sample and individual based species accumulation curves were calculated for each land use (Kindt \& Coe 2005).

Ordination was used to show bird species associations and their relationship with land use and season. Canonical analysis of principle coordinates (CAP) (Anderson \& Willis 2003) with the Odum similarity measure was used with the walks divided into 6 classes by land use and season. Species abundances were transformed using $\log ($ abundance +1$)$ for the ordination to prevent the results being dominated by the few flocking species with very large numbers of individuals seen on few walks.

\section{Results}

A total of 119 species were seen. Table 2 compares the number of species and diversity of the three land use categories. As it became apparent that the species diversity and composition was very different in the two types of highland environments, highland data was analysed separately in the diversity analysis. A highland garden has the highest diversity index, followed by homegardens and bushland. Lowlands, with the highest number of individuals and as high number of species as in highlands, ranks as the least diverse when measured by Shannon-Weaver index as the distribution is very uneven, with large numbers of just a few flocking species. 
Table 2. Comparing bird diversity and species and individual numbers in three habitat types on the south-eastern slopes of Mt. Kilimanjaro and the adjacent plains

\begin{tabular}{|c|c|c|c|c|c|c|}
\hline Habitat & $\begin{array}{l}\text { Number } \\
\text { of } \\
\text { species }\end{array}$ & $\begin{array}{l}\text { Number of } \\
\text { individuals }\end{array}$ & $\begin{array}{c}\text { Number of } \\
\text { walks }\end{array}$ & $\begin{array}{l}\text { Average number of } \\
\text { individuals per walk } \\
\text { (range) (range/season) }\end{array}$ & $\begin{array}{l}\text { Average number of species } \\
\text { per walk (per season) }\end{array}$ & $\begin{array}{l}\text { Diversity } \\
\text { Index }(H\end{array}$ \\
\hline & 57 & 1625 & 12 & $135(23-498)$ & 13 & \\
\hline \multirow[t]{2}{*}{ Lowland fields } & & & & (127 in May-July, 152 in Nov & (15 in May-July, 10.3 in Nov) & 2.624 \\
\hline & 43 & 540 & 12 & $45(24-71)^{1}$ & 11.8 & \\
\hline \multirow[t]{2}{*}{ Bushland } & & & & (45 in May-July, 46 in Nov) & (11 in May-July, 13 in Nov) & 2.988 \\
\hline & 57 & 771 & 12 & $64(11-125)$ & 16.2 & \\
\hline Highlands & & & & (62 in May-July, 68.5 in Nov) & (15 in May-July, 19.5 in Nov) & 3.293 \\
\hline Homegarden & 32 & & 5 & $38(11-62)$ & & 3.067 \\
\hline Highland garden & 49 & & 7 & $83(50-125)$ & & 3.147 \\
\hline \multicolumn{7}{|c|}{${ }^{1}$ Five individuals on Nanga hill } \\
\hline \multicolumn{7}{|c|}{ The sample-based species accumulation curves (Fig. 2 a) show that the sample sizes of 12 walks per land } \\
\hline \multirow{2}{*}{\multicolumn{7}{|c|}{$\begin{array}{l}\text { use were large enough to detect major differences in species numbers. The curves have not flattened, so } \\
\text { further walks would be expected to detect more species. The right hand end of the curve for lowland is }\end{array}$}} \\
\hline & & & & & & \\
\hline \multicolumn{7}{|c|}{ steeper than that for highland, so the total number of species is probably higher in the lowlands. That the } \\
\hline
\end{tabular}


a)

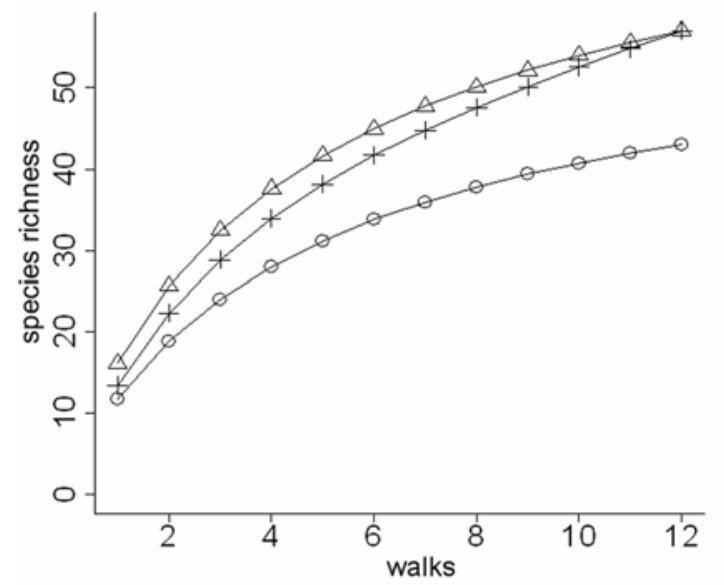

b)

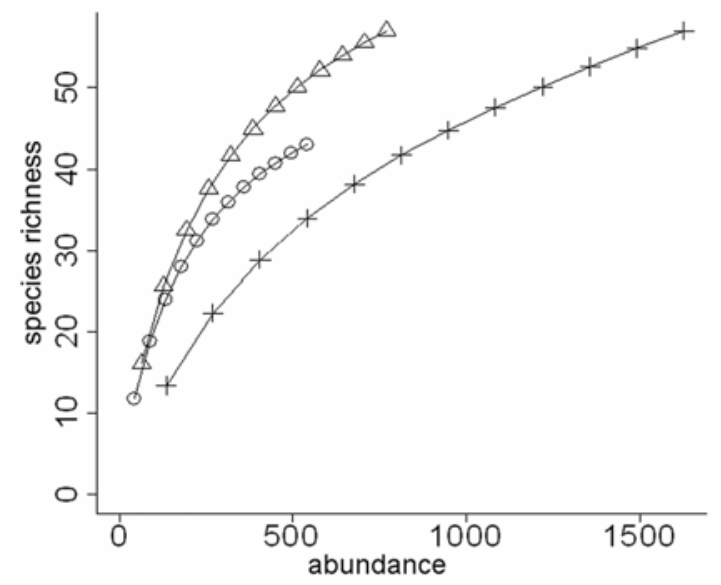

Figure 2. Species accumulation curves for birds in the lowlands $(+)$, bushland $(O)$ and highlands $(\triangle)$ on the south-eastern slopes of Mt. Kilimanjaro. (a) Walk-based curves, (b) Individual-based curves.

Lowlands have higher abundances of birds (Table 2), and hence higher species numbers are to be expected. The extent to which differences in species numbers are explained by differences in abundance is revealed by the individual based species accumulation curves (Fig. 2 b). On a 'per bird' scale, highlands have most species, with lowlands the fewest. The few flocking species are responsible for this result, with the curves for each land use being almost identical if 3 flocking species are dropped from the analysis (data not shown).

Figure 3 shows the rank abundance curves for all three land use categories. Lowlands have very high number of individuals of only three species. Bushland has one species well above the others. Highlands represent a land use category with lowest number of individuals, but a more even distribution. 


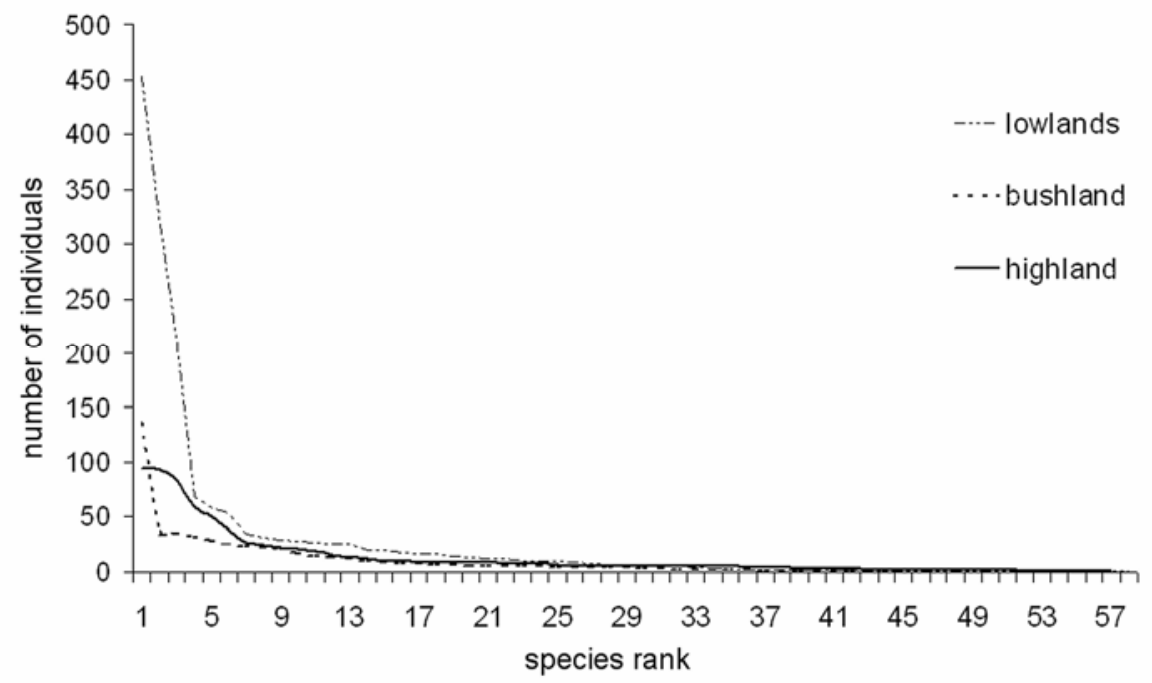

Figure 3. Bird species rank abundance in the lowlands, bushland and highlands on the south-eastern slopes of Mt. Kilimanjaro.

Cultivated lowland and bushland show highest similarity $(\mathrm{SI}=0.42)$. This is partly because these two land use categories are in the same altitude. Another explanation may be the proximity of the highland sample area to the natural forests of the Kilimanjaro Forest Reserve making the bird communities of the highlands more similar to the forest bird communities. How well tree based agricultural systems have been found to support forest bird communities elsewhere is discussed later in this paper (see Discussion). Similarity indices for bushland and highlands, and lowlands and highlands were 0.28 and 0.18 respectively. All land use categories had a considerable number of species that were not seen in another land use category, 33 species in lowlands, 15 species in bushland, and 39 species in the highlands (Table 3), which suggests that differences in bird communities are a result of land use and not only altitude. Only six species were seen in all land use categories.

Much of the bird activity in the lowland field area is concentrated in and around the scattered trees in the fields and rows of trees along the roads. Crops were just ripening during the May-July survey and attracted big flocks of Chestnut Weavers (Ploceus rubiginosus) and Wattled Starlings (Creatophora cinerea). The number of individuals of these species in May-July is well above any other species being 318 for Chestnut weavers and 216 for Wattled Starlings. Grosbeak Weavers (Amblyospiza albifronz) were also numerous. All these most numerous species were absent in November. In November, two months after the crops had been harvested, large flocks of Red-billed Queleas (Quelea quelea) were the most numerous species. Over 400 individuals were counted. The next most numerous species were Long-tailed Fiscal (Lanius cabanisi) and Speckled Mousebird (Colius striatus), but these two were present in both seasons. Thirty-three of the 
lowland species were present in May-July only, eleven (out of which two are migrants) were spotted in November only.

Common Bulbul (Pycnonotus barbatus) was the most numerous species in the bushlands, with nearly four times as many as the next most numerous species. Trilling Cisticola (Cisticola woosnami), Pied Crow (Corvus albus), Speckled Mousebird (Colius striatus) and Yellow-rumped seedeater (Serinus reichenowi) all had more than 30 sightings. One evening walk was done on the small Nanga hill, but only four species were spotted during a two-hour walk. Seventeen bushland species were spotted in May-July only, nine (out of which two migrants) in November only.

Highlands had several numerous species. The most common ones were the Common Bulbul (Pycnonotus barbatus), Variable sunbird (Cinnyris venusta), Speckled Mousebird (Colius striatus), Black-and-white Mannikin (Lonchura bicolor) and Baglafecht Weaver (Ploceus baglafecht). Seventeen highland species were spotted in May-July only, sixteen in November only (out of which two are migrants).

The ordination (Fig 4) confirms two important results. First, there are distinct associations of bird species in each land use. There is no overlap in the samples from each different land use. In other words, given a sample record of species and abundance there would be no confusion as to which land use it came from. Secondly, differences in bird associations between land uses are larger than between seasons, with the only noticeable seasonal difference in the lowlands. 


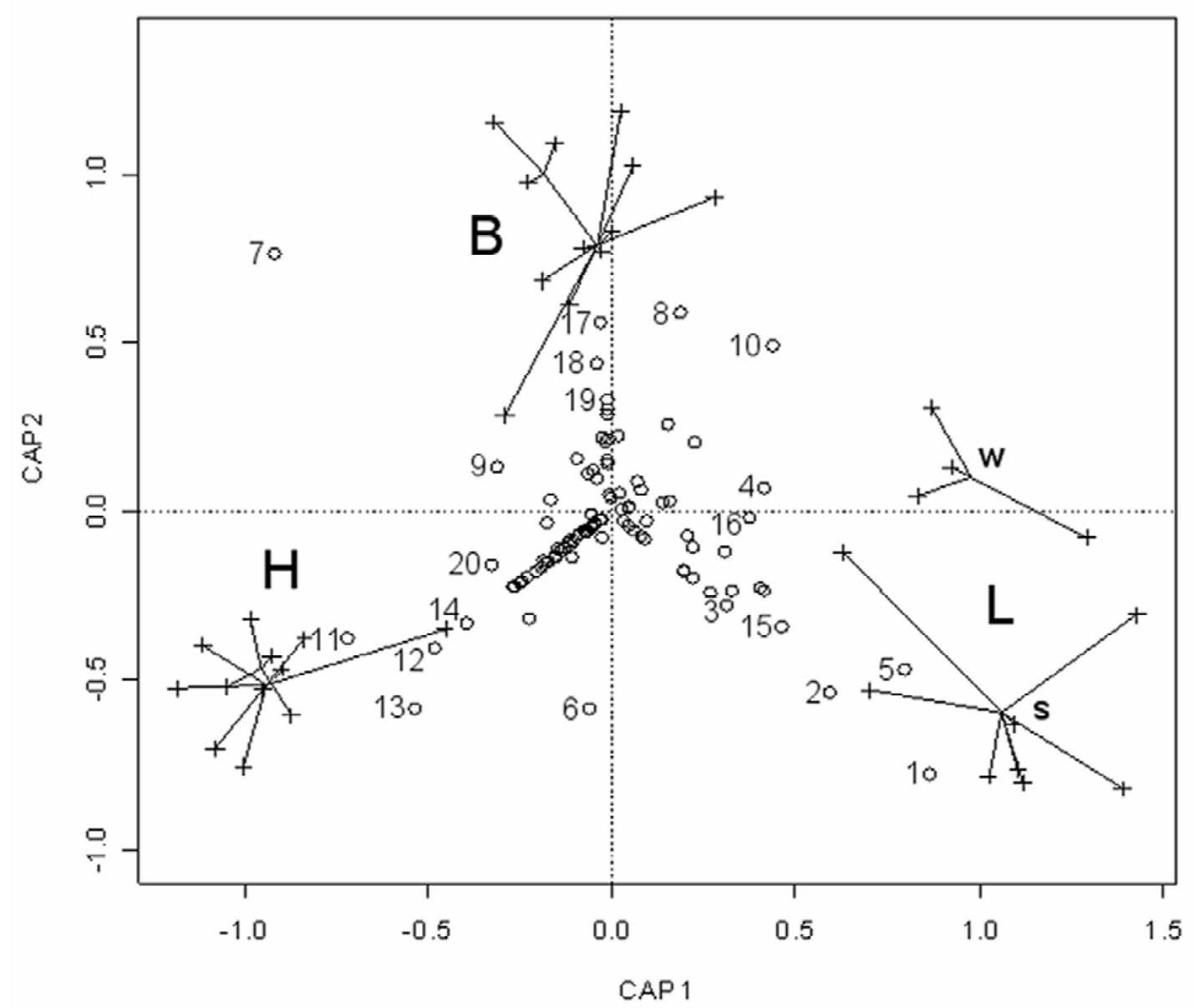

Figure 4. Ordination of bird species using a canonical principle coordinates analysis. Species $(O)$ and walks $(+)$ are plotted on the first two principle axes. Points for walks are connected to the centroid of the observations for that land use (L: lowland, B: bushland, $H$ : highland) and season ( $S$ : May-July, W: November). Species most characteristic of each land use are labelled 1: Chestnut Weaver, 2: Wattled Starling, 3: Grosbeak Weaver, 4: Red-billed Quelea, 5: Long-tailed Fiscal, 6: Speckled Mousebird, 7: Common Bulbul, 8: Trilling Cisticola, 9: Pied Crow, 10: Yellow-rumped Seedeater, 11: Variable Sunbird, 12: Black-and-white Mannikin, 13: Baglafecht Weaver, 14: Whiteeyed Slaty Flycatcher, 15: African Mourning Dove, 16: White-browed Sparrow-Weaver, 17: Cinnamon-breasted Rock Bunting, 18: Grey Wren-Warbler, 19: Blue-naped Mousebird, 20: Redeyed Dove. 


\section{Discussion}

A large amount of research on bird diversity emphasises the general negative effects of forest conversion to human dominated habitats (e.g. Myers 1992; Brooks et al. 1997; Castelletta et al. 2000). But human dominated and agricultural habitats vary a lot and therefore the effect on birds can be very different. Tworek (2002) showed that responses of birds to habitat changes differ depending on their strategies. Some lifestyles benefit from habitat change, while for others it is a principal threat.

Can tree based agricultural systems like the Chagga homegardens substitute natural forest for bird communities, and how well? Some conclusions can be made using research results from elsewhere. Reitsma et al. (2001) concluded from a study of cacao plantations in Costa Rica that although cacao plantations cannot substitute for forest, they provide habitat for a large number of bird species that depend to some degree on forests. Similar studies of shaded coffee systems have been done by Perfecto et al. (1996) and Perfecto and Vandermeer (2002). Thiollay (1995) studied different types of agroforestry systems of Sumatra and found that bird species richness, diversity, and equitability were all significantly lower (12 - $62 \%$ less) in every agroforest than in the primary forest, and the similarity between the natural and managed forest communities were low. Kara (1995) studied bird species composition and activities in two different highland habitats on the slopes of Kilimanjaro, moderately modified riverine forest and a severely disturbed riverine forest (the latter is a coffee-banana dominated homegarden). There was a reduction in bird species diversity, especially in the shrubby layer, due to constant weeding and mulching in the severely disturbed habitat, but species composition was very similar in the tree canopy in the two habitats. The intense habitat alteration has contributed to the decrease in numbers and complete disappearance of many species of birds (Moreau 1944) and mammals (Newmark et al. 1991) from the inhabited slopes of Mt. Kilimanjaro.

Naidoo (2004) studied bird diversity across different stages of forests and agricultural land in Mabira forest in Uganda and found that tree density is the only vegetation variable that is a significant predictor of the number of bird species. In his study, increased tree density was associated with increased number of bird species regardless of land use type. However, Naidoo (2004) states that raising the tree density of the agricultural areas around Mabira forest to 126 trees/ha would have little general impact on making the songbird community structure similar to forest communities, except in a $400 \mathrm{~m}$ zone next to an intact forest, where the community similarity between an agroforest and the intact forest would increase by one third. It is important to keep in mind that Naidoo's statement applies to the community structure of birds, not high diversity per se. According to him, current and best practices in agriculture are therefore unlikely 
to contribute to the conservation of the songbird component of the forest biodiversity in his study area. From the information on number of trees per farm given by O'kting'ati \& Hussein (1986) one can estimate a tree density of 57 trees/ha in the Chagga Homegardens in the 1980's. This sounds realistic as the survey has most probably counted only big trees. Many of the trees in the homegardens are very big, and the above density means that trees roughly thirteen metres apart can form closed canopy. The Chagga homegardens, far from the tree densities of Naidoo's (2004) speculation, would not be able to substitute a forest for forest birds. As there is no original forest left in the same altitudes as the homegardens in the study area (or the whole southern slopes of Kilimanjaro), comparison of differences of tree densities and bird diversity of intact forests and homegardens is impossible. It is more informative to compare the homegardens with the highland garden rather than with an intact forest as an increasing number of homegardens are turning into highland gardens (Soini 2005 b). In this context it is interesting that Jones \& Eason (1995) found that just the presence of trees increases bird activity.

Homegardens are an agricultural system with an unusual diversity of plant species, but they are not very niche diverse. Fifty-three trees, 29 food crops, 21 other useful non-woody species and eight weed species have been identified in the Chagga homegardens (O'ktingati et al. 1984), but the system is dominated by coffee and banana. Due to the agricultural system and constant mulching of the ground strata the variety of food available in the coffee-banana system for birds is low. Also, such niches as open spaces and thickets, which are abundant in the highland garden, are not common in the homegardens.

Human disturbance to birds is frequent in the homegarden area. Farms are small, houses are close together, and the area has a very dense network of busy footpaths. The average plot size is 0.6 hectares (Soini 2005 $\mathrm{a}, \mathrm{b}$ ) which leaves approximately $77 \mathrm{~m}$ between the main houses of neighbouring farms. Counting tin roofs from an aerial photo of the year 2000 (Photomap Kenya Ltd.) from two random locations in the homegarden area in Kirua Vunjo gives even a shorter distance (about $50 \mathrm{~m}$ ) between the houses.

Some studies that compare bird species and diversity between forested and different types of agricultural areas show that forested areas contain more species than agricultural areas (Blankespoor 1991; Ranjit Daniels et al. 1992; Andrade \& Rubio-Torgler 1994; Thiollay 1995; Estrada et al. 1997; Daily et al. 2001). However, some species may benefit from agriculture (e.g. Wolf et al. 2001). There can be a positive association between numbers of some species and arable habitat especially in areas where arable habitat is rare in the surrounding area (Robinson et al. 2001). On Mt. Kilimanjaro most of the lowland bushlands have been gradually converted to agricultural land. These agricultural lands support a much higher number of birds than the remaining bushland. However, only half of the bushland species were found in these lowland agricultural fields. Also, for example Sinclair et al. (2002) document a substantial but previously unnoted loss of bird diversity in agriculture detected by reference to the immediately adjacent native 
savannah vegetation. In their study the abundance of species found in agriculture was only $28 \%$ of that for the same species in native savannah.

Only very stony areas with shallow soils have remained uncultivated bushland and are used as grazing land (Maro 1974; Soini 2005 b). These remaining bushlands are small fragments in the middle of the lowland agricultural fields. Riverine woodland have become very narrow with only a row or two of trees remaining along a watercourse and these are increasingly threatened by firewood and timber collection. A likely group of threatened species in the study area are the riverine bird species which were found, but not treated as a separate group in this study due to the very small areas.

Several studies have been done on landscape and habitat fragmentation affecting species viability (e.g. Winter \& Faaborg 1999; Cornelius et al. 2000; Zanette 2000; Zanette et al. 2000; Johnson \& Igl 2001; Beier et al. 2002; Herkert et al. 2003; Kurosawa \& Askins 2003). Fragmentation usually leads to species decrease or eventually species absence.

Lowlands are seemingly very rich in birds. However, the diversity is not high as the land use type is dominated by flocking birds. The low diversity index seems to reflect the overall diversity of the agricultural system in the lowlands. The land is dominated by open fields of maize and beans, with some millet, sunflower and groundnuts in between. This area is the main food crop area of the Chagga. One might assume that the flocks of hundreds of birds would cause significant destruction on the maize, millet and sunflower crops in the area. However, in the interview survey by Soini (2005 a, b) farmers never identified birds as a problem, nor have farmers erected any bird deterrents. Both the northern summer survey (May-July) and northern winter survey (November) were done at times when there was very little agricultural activity in the lowlands. During land preparation (usually January-March), planting (March), weeding (till May) and harvesting times (July-August) human disturbance is at its peak in the Lowlands (Fernandes et al. 1984; Zongolo et al. 2000). More studies are needed on the effects of different agricultural activities during different times of the year.

The two seasons were selected in order to capture variation in the presence of migratory species and to capture variation in bird communities between the rainy and dry seasons. This study revealed only a few known northern migrants, but there were large differences in the most numerous species between the two seasons in the lowlands. It seems that two observation times during the year are not adequate to understand the seasonal variation in bird communities and the impact of intra-African migration. From this data it is not possible to predict what might have been observed at other seasons. 
It is apparent that the number of walks done for this study cannot reveal all the species present in the land use categories. However, the records can give useful indication of the relative levels of diversity in the three land use categories. More species were spotted on each subsequent walk. The difference in species number between homegardens (32) and highland garden (49) would not be as big if the same number of walks had been done in both areas. However, it is obvious that two additional walks in homegardens cannot add seventeen more species and in so doing change the main conclusion of this study concerning these two highland sub categories.

Detectability of birds varies in the three land use categories. Birds are more easily spotted in the lowland fields, highland garden and bushlands (in that order) than in the homegardens. It is possible that some birds were missed in treetops of the tall trees in the homegarden area. However, this is not considered to be a significant bias as several species were spotted in the tree canopy. A clear bias was caused identifying birds $30 \mathrm{~m}$ on either side of the transects as high flying birds such as swallows and swifts were not recorded.

One main route in each land use category was located near a stream. In addition, one main lowland route ended half a kilometre from Miwaleni springs, a large spring on the southern boundary of the study area. The highland garden was next to a stream and one homegarden route crossed a stream (in addition of both crossing irrigation furrows). Species preferring areas close to water are therefore expected to occur in all land use categories.

\section{Conclusions}

The majority (87/119) of species seen were restricted to a single land use category. This has consequences as land use changes. It is significant especially in the context of overexploitation of the small fragments of bushland areas. Even if the bushland species will not become endangered species in the true meaning of the word, some species will disappear from the area if the destruction of bushland fragments continues. These would be the fifteen species found only in the bushlands (see Appendix) which are apparently not capable of adapting to the neighbouring land use categories.

Other studies of the relationship between number of trees and number and diversity of birds would predict that the Chagga homegarden system is the most diverse land use category type in the area. However, this study concludes that the presence of trees, not the density of trees, is a critical factor for diversity, concurring with Jones \& Eason (1995). The highland garden had the highest Shannon-Weaver index of bird diversity. As a quiet area with a variety of fruit and flower trees, shade and sunshine, grass, flowerbeds, a vegetable garden area, hedges, open space, thickets and buildings, a highland garden is a very niche diverse 
land use category. The number of birds spotted in the highland garden per a bird walk was double that of the immediately adjacent homegardens which have the second highest Shannon-Weaver index.

Continuing high population growth and pressure on land in the homegarden area will force farmers to further subdivide their farms. This will go on until the plots are too small to be divided any more. Some farms have already reached that state, and the subdivided units cannot function as farms. This development will gradually change the nature of the area. The typically agricultural homegarden area will become more like a sub-urban area. How exactly this will affect bird life is difficult to predict. Due to the increasing number of buildings, yards and vegetable gardens the number of trees in the homegarden area will continue to decrease. The new highland gardens that the process creates will be much smaller than the highland garden of this study, and due to the high population density human disturbance will be high. It is, however, likely that the small highland gardens will have less human activities than current homegardens where agricultural activities are going on most of the day throughout the year. It is not clear whether the impact of human disturbance due to very high human population density will prevent the area from supporting a highland garden type of a bird population. Land use category preference and response to habitat change by birds is a complex issue with several interacting factors playing a role. It is important to formulate future research questions on bird diversity in the area in a way that can clearly distinguish between the different biophysical factors of the land use categories and the human disturbance that is likely to be one of the most crucial factors in determining the bird diversity level of a land use type. 


\section{Appendix}

Bird species spotted in the three habitats of highlands, bushlands and lowland fields on the southern slopes of Mt. Kilimanjaro. Naming according to Stevenson \& Fanshawe, 2002.

\begin{tabular}{|c|c|c|c|c|}
\hline Common name & Scientific name & $\begin{array}{l}\text { Where spotted } \\
\text { (L=lowlands, } \\
\text { B=bushland, } \\
\text { H=highlands) }\end{array}$ & $\begin{array}{l}\text { Total } \\
\text { abundance }\end{array}$ & When spotted \\
\hline \multicolumn{5}{|l|}{ Ardeidae (Herons, Egrets and Bitterns) } \\
\hline Black-headed Heron & Ardea melanocephala & $\mathrm{L}$ & 10 & May-July \&Nov \\
\hline Cattle Egret & Bubulcus ibis & L & 27 & Nov \\
\hline \multicolumn{5}{|c|}{ Threskiornithidae (Ibises and Spoonbills) } \\
\hline Hadada Ibis & Bostrychia hagedash & $\mathrm{H}$ & 5 & Nov \\
\hline \multicolumn{5}{|c|}{ Accipitridae (Vultures, Eagles, Hawks, Kites, and allies) } \\
\hline Black-shouldered Kite & Elanus caeruleus & $\mathrm{L}$ & 1 & Nov \\
\hline Pallid/Montagu's Harrier ${ }^{\mathrm{m}}$ & Circus macrourus/C. pygargus & $B, L$ & 2 & Nov \\
\hline Little Sparrowhawk & Accipiter minullus & L & 2 & Nov \\
\hline Augur Buzzard & Buteo augur & $B, L$ & 6 & May-July \&Nov \\
\hline Long-crested Eagle & Lophaetus occipitalis & $\mathrm{L}$ & 2 & May-July \\
\hline \multicolumn{5}{|l|}{ Otididae (Bustards) } \\
\hline Kori Bustard & Ardeotis kori & $\mathrm{L}$ & 2 & May-July \\
\hline \multicolumn{5}{|l|}{ Charadriidae (Plovers) } \\
\hline Crowned Lapwing & Vanellus coronatus & $L$ & 12 & Nov \\
\hline \multicolumn{5}{|l|}{ Columbidae (Pigeons and Doves) } \\
\hline African Green-Pigeon & Treron calva & B & 13 & May-July \\
\hline Tambourine Dove & Turtur tympanistria & $\mathrm{H}$ & 1 & May-July \\
\hline Emerald-spotted Wood-Dove & Turtur chalcospilos & B & 1 & May-July \\
\hline Red-eyed Dove & Streptopelia semitorquata & $B, H$ & 23 & May-July \&Nov \\
\hline African Mourning Dove & Streptopelia decipiens & $L$ & 26 & May-July \&Nov \\
\hline Ring-necked Dove & Streptopelia capicola & $B, L$ & 14 & May-July \&Nov \\
\hline Laughing Dove & Streptopelia senegalensis & $B, L$ & 22 & May-July \\
\hline \multicolumn{5}{|l|}{ Cuculidae (Cuckoos and Coucals) } \\
\hline Red-chested Cuckoo & Cuculus solitarius & $\mathrm{H}$ & 6 & Nov \\
\hline Common Cuckoo ${ }^{\mathrm{m}}$ & Cuculus canorus & $\mathrm{H}$ & 1 & May-July \&Nov \\
\hline Klaas's Cuckoo & Chrysococcyx klaas & B & 1 & May-July \\
\hline White-browed Coucal & Centropus superciliosus & $\mathrm{B}, \mathrm{H}, \mathrm{L}$ & 40 & May-July \&Nov \\
\hline
\end{tabular}

Caprimulgidae (Nightjars) 
Coliidae (Mousebirds)

$\begin{array}{ll}\text { Speckled Mousebird } & \text { Colius striatus } \\ \text { Blue-naped Mousebird } & \text { Urocolius macrourus }\end{array}$

Alcedinidae (Kingfishers)

Grey-headed Kingfisher

African Pygmy Kingfisher

Meropidae (Bee-eaters)

Little Bee-eater

Coraciidae (Rollers)

Lilac-breasted Roller

Bucerotidae (Hornbills)

African Grey Hornbill

Tockus nasutus

Crowned Hornbill

Silvery-cheeked Hornbill
Halcyon leucocephala

Merops pusillus

Coracias caudata

Tockus alboterminatus

Bycanistes brevis
Ispidina picta

Capitonidae (Barbets and Tinkerbirds)

$\begin{array}{ll}\text { Moustached Green Tinkerbird } & \text { Pogoniulus leucomystax } \\ \text { Spot-flanked Barbet } & \text { Tricholaema lachrymosa } \\ \text { White-headed Barbet } & \text { Lybius leucocephalus } \\ \text { Brown-breasted Barbet } & \text { Lybius melanopterus }\end{array}$

Indicatoridae (Honeyguides and Honeybirds)

Greater Honeyguide

Indicator indicator

Picidae (Wrynecks and Woodpeckers)

Grey Woodpecker

Dendropicos goertae

Motacillidae (Wagtails, Pipits and Longclaws)

$\begin{array}{ll}\text { African Pied Wagtail } & \text { Motacilla aguimp } \\ \text { Mountain Wagtail } & \text { Motacilla clara } \\ \text { Long-billed Pipit } & \text { Anthus similis } \\ \text { Pangani Longclaw } & \text { Macronyx aurantiigula }\end{array}$

Pycnonotidae (Bulbuls, Greenbuls and Brownbuls)

Zanzibar Sombre Greenbul

Andropadus importunus

Common Bulbul

Pycnonotus barbatus

Turdidae (Thrushes, Robins, Chats and relatives)

$\begin{array}{ll}\text { Ruppell's Robin-Chat } & \text { Cossypha semirufa } \\ \text { Cape Robin-Chat } & \text { Cossypha caffra } \\ \text { Spotted Morning-Thrush } & \text { Cichladusa guttata } \\ \text { Nightingale }^{m} & \text { Luscinia megarhynchos } \\ \text { White-browed Scrub-Robin }^{\text {Common Stonechat }} & \text { Cercotrichas leucophrys } \\ \text { Caxicola torquata }\end{array}$

B, H, L

B

H, L

$\mathrm{H}$

B, L

L

B, L

$\mathrm{H}$

$\mathrm{H}$

174

21

May-July \&Nov

May-July

May-July

Nov

May-July

May-July

May-July \&Nov

May-July \&Nov

May-July

$\mathrm{H}$

$\mathrm{H}$

B

$\mathrm{H}$

L

2

May-July

L

1

May-July

H

$\mathrm{H}$

B

L

L

B, H, L

2

235

$\mathrm{H}$

$\mathrm{H}$

B, L

\section{B}

B, L

$\mathrm{H}$
May-July

May-July \&Nov

Nov

May-July

May-July

May-July

May-July
y-July \&Nov

Nov May-July \&Nov Nov

Nov

May-July

May-July 
Olive Thrush

Sylviidae (Warblers)

Garden Warbler ${ }^{\mathrm{m}}$

Singing Cisticola

Trilling Cisticola

Hunter's Cisticola

Winding Cisticola

Rattling Cisticola

Ashy Cisticola

Siffling Cisticola

Tawny-flanked Prinia

Grey Wren-Warbler

Grey-backed Camaroptera

Red-faced Crombec

Somali Long-billed Crombec

Muscicapidae (Flycatchers)

White-eyed Slaty Flycatcher

Pale Flycatcher
Buff-bellied Warbler

Turdus olivaceus

Sylvia borin

Cisticola cantans

Cisticola woosnami

Cisticola hunteri

Cisticola galactotes

Cisticola chiniana

Cisticola cinereolus

Cisticola brachypterus

Prinia subflava

Calamonastes simplex

Camaroptera brachyura

Sylvietta whytii

Sylvietta isabellina

Phyllolais pulchella

Melaenornis fischeri

Bradornis pallidus

Platysteiridae (Batises and Wattle-eyes)

Chin-spot Batis
Black-throated Wattle-eye

Batis molitor

Platysteira peltata

Monarchidae ( Monarch flycatchers)

African Paradise-flycatcher

Terpsiphone viridis

Zosterops abyssinicus

Abyssinian White-eye

Nectariniidae (Sunbirds)

Collared Sunbird

Olive Sunbird

Amethyst Sunbird

Hunter's Sunbird

Variable Sunbird

Bronze Sunbird

Laniidae (Shrikes)

$$
\text { Long-tailed Fiscal }
$$

Common Fiscal

Malaconotidae (Bush-Shrikes)

Brown-crowned Tchagra

Tropical Boubou

Hedydipna collaris

Cyanomitra olivacea

Chalcomitra hunteri

Cinnyris venusta

Nectarinia kilimensis

Lanius cabanisi

Lanius collaris

Tchagra australis

Laniarius aethiopicus
$\mathrm{H}$

4

May-July

\section{L}

$\mathrm{H}$

B, L

$\mathrm{H}$

L

\section{L}

L

B

B, L

B

$\mathrm{H}$

L

B

L

$\mathrm{H}$

L

May-July \&Nov

Nov

B, $\mathrm{H}$

$\mathrm{H}$

B, H, L

13

May-July \&Nov

B, H

19

May-July

H

H

$\mathrm{H}$

B, L

B, H, L

$\mathrm{H}$

12

May-July

May-July

Chalcomitra amethystina

L

B, $\mathrm{H}$

68

May-July \&Nov

B, $\mathrm{H}$

May-July \&Nov
$\mathrm{H}$
Nov 
Black-backed Puffback

\section{Campephagidae (Cuckoo-shrikes)}

Black Cuckoo-shrike

Oriolidae (Orioles)

African Black-headed Oriole

Corvidae (Crows and allies)

Pied Crow

Sturnidae (Starlings and Oxpeckers)

Red-winged Starling
Greater Blue-eared Starling
Hildebrandt's Starling
Superb Starling
Violet-backed Starling
Wattled Starling

Passeridae (Sparrows and Petronias)

Grey-headed Sparrow

Yellow-spotted Petronia

Ploceidae (Weavers)

White-browed Sparrow-Weaver

Grosbeak Weaver

Baglafecht Weaver

Spectacled Weaver

Black-headed Weaver

Chestnut Weaver

Red-headed Weaver

Red-billed Quelea

Emberizidae (Waxbills)

\begin{tabular}{|c|c|}
\hline Red-billed Firefinch ${ }^{1}$ & Lagonosticta senegala \\
\hline African Firefinch ${ }^{1}$ & Lagonosticta rubricata \\
\hline Blue-capped Cordon-bleu & Uraeginthus cyanocephalus \\
\hline Southern Cordon-bleu & Uraeginthus angolensis \\
\hline Black-and-white Mannikin ${ }^{2}$ & Lonchura bicolor \\
\hline Bronze Mannikin ${ }^{2}$ & Lonchura cucullata \\
\hline Magpie Mannikin & Lonchura fringilloides \\
\hline Black-winged Red Bishop & Euplectes hordeaceus \\
\hline White-winged Widowbird & Euplectes albonotatus \\
\hline Pin-tailed Whydah & Vidua macroura \\
\hline African Golden-breasted Bunting & Emberiza flaviventris \\
\hline Cinnamon-breasted Rock & Emberiza tahapisi \\
\hline
\end{tabular}

Campephaga flava

Corvus albus

Onychognathus morio

Lamprotornis chalybaeus

Lamprotornis hildebrandti

Lamprotornis superbus

Cinnyricinclus leucogaster

Creatophora cinerea

Passer griseus

Petronia pyrgita

Plocepasser mahali

Amblyospiza albifrons

Ploceus baglafecht

Ploceus ocularis

Ploceus cucullatus

Ploceus rubiginosus

Anaplectes rubriceps

Quelea quelea
$\mathrm{H}$

9

May-July

L

1

May-July

Oriolus larvatus

L

May-July

B, H, L

78

May-July \&Nov

H

L

B, L

L

H, L

$\mathrm{H}$

$\mathrm{H}, \mathrm{L}$

L

B, $\mathrm{H}$

L

$\mathrm{H}, \mathrm{L}$ ?

$B, H$ ?

B

L

H

$\mathrm{H}$

$\mathrm{H}$

L

B

L

$\mathrm{H}$

B

$\begin{array}{cc}5 & \text { May-July } \\ 3 & \text { Nov } \\ 2 & \text { May-July } \\ 30 & \text { May-July \&Nov } \\ 15 & \text { May-July \&Nov } \\ 216 & \text { May-July }\end{array}$

May-July \&Nov

May-July

May-July \&Nov

May-July

May-July \&Nov

May-July \&Nov

May-July \&Nov

$$
\text { May-July }
$$

May-July

Nov

453

64

May-July \&Nov

May-July \&Nov

May-July \&Nov

May-July \&Nov

May-July \&Nov?

May-July \&Nov?

May-July

May-July

Nov

May-July

Nov

May-July \&Nov 
Bunting

Fringillidae (Seedeaters and Canaries)

$\begin{array}{ll}\text { Streaky Seedeater } & \text { Serinus striolatus } \\ \text { Yellow-rumped Seedeater } & \text { Serinus reichenowi } \\ \text { Yellow-crowned Canary } & \text { Serinus canicollis } \\ \text { African Citril } & \text { Serinus citrinelloides } \\ \text { Yellow-fronted Canary } & \text { Serinus mozambicus } \\ \text { White-bellied Canary } & \text { Serinus dorsostriatus } \\ \text { Brimstone Canary } & \text { Serinus sulphuratus }\end{array}$

$\begin{array}{ccc}\text { H } & 2 & \text { Nov } \\ \text { B, L } & 62 & \text { May-July \&Nov } \\ \text { H } & 6 & \text { May-July \&Nov } \\ \text { H } & 10 & \text { May-July \&Nov } \\ \text { H } & 2 & \text { Nov } \\ \text { B, L } & 28 & \text { May-July } \\ \text { B } & 1 & \text { Nov }\end{array}$

${ }^{\mathrm{m}}$ Northern migrant

${ }^{1}$ Some misidentification between these two species: Information on occurrence in one habitat only not reliable

${ }^{2}$ Some misidentification between these two species: Combined number given only, occurrence in one or both seasons not reliable. 


\section{References}

Anderson, G.D. 1982. (Revised edition of 1968 paper). A survey of soils and land use potential of the southern and eastern slopes of Mt. Kilimanjaro, Tanzania. Resource management paper no 1. Institute of Resource Assessment, University of Dar es Salaam and International Develoment Programme, Clark University, Worcester, Massachusets.

Anderson, M.J. \& Willis, T.J. 2003. Canonical analysis of principal coordinates: a useful method of constrained ordination for ecology. Ecology 84: 511-525.

Andrade, G.I. \& Rubio-Togler, H. 1994. Sustainable use of the tropical rain forest: evidence from the avifauna in a shifting-cultivation habitat mosaic in the Colombian Amazon. Conservation Biology 8: $545-554$.

Beier, P., Van Drielen, M.\& Kankam B.O. 2002. Avifaunal collapse in West African forest fragments. Conservation Biology 16: 1097-1111.

Blankespoor, G.W. 1991. Slash-and-burn shifting agriculture and bird communities in Liberia. West African Biological Conservation 57: 41-71.

Britton, P.L. (ed.) 1980 and 1996. Birds of East Africa. East Africa Natural History Society, Nairobi.

Brooks, T.M., Pimm, S. L. \& Collar, N. J. 1997.Deforestation predicts the number of threatened birds in insular southeast Asia. Conservation Biology 11: 382-394.

Canterbury, G.E., Martin, T.E.,Petit, D.R., Petit, L.J. \& Bradford, D.F. 2000. Bird communities and habitat as ecological indicators of forest condition in regional monitoring. Conservation Biology 14: 544-558.

Castelletta, M., Sodhi, N. S. \& Subaraj, R. 2000. Heavy extinctions of forest avifauna in Singapore: lessons for biodiversity conservation in Southeast Asia. Conservation Biology 14: 1870-1880.

Chase, M.K., Kristan III, W.B., Lynam, A.J., Price, M.V. \& Rotenberry, J.T. 2000. Single species as indicators of species richness and composition in California coastal sage scrub birds and small mammals. Conservation Biology 14: 474-487.

Cornelius , C., Cofre, H. \& Marquet, P.A. 2000. Effects of habitat fragmentation on bird species in a relict temperate forest in semiarid Chile. Conservation Biology 14: 534-543.

Daily, G. C., Ehrlich, P. R. \& Sanchez-Azofeifa, G. A. 2001. Countryside biogeography: use of humandominated habitats by the avifauna of southern Costa Rica. Ecological Applications 11: 1-13.

Estrada, A., Coates-Estrada, R. \& Meritt, D. A. 1997. Anthropogenic landscape changes and avian diversity at Los Tuxtlas, Mexico. Biodiversity Conservation 6: 19-43.

Fernandes, E.C.M, O'kting'ati, A. \& Maghembe, J. 1984. The Chagga homegardens: a multistoried agroforestry cropping system on Mt. Kilimanjaro (Northern Tanzania). Agroforestry Systems 2: 73-86.

Herkert, J.R., Reinking, D.L., Wiedenfeld, D.A., Winter M., Zimmerman, J.L., Jensen, W.E., Finck, E.J., Koford, R.R., Wolfe, D.H., Sherrod, S.K., Jenkins, M.A., Faaborg, J. \& Robinson, S.K. 2003. Effects of prairie fragmentation on the nest success of breeding birds in the midcontinental United States. Conservation Biology 7: 587-594.

Johnson, D. H. \& Igl, L. D. 2001. Area requirements of grassland birds: a regional perspective. The Auk 118: 24-34.

Jones, D. \& Eason, W.R. 1995. The influence of a developing agroforestry system on bird population dynamics. Quarterly Journal of Forestry 89: 120-125.

Kara, C.J. 1995. The Effects of agroforestry practices on the biological diversity of birds and indigenous plants on the southern slopes of Mt. Kilimanjaro. TRI News 14: 15-18. 
Kindt, R. \& Coe, R. 2005. Tree diversity analysis. A manual and software for common statistical methods for ecological and biodiversity studies. World Agroforestry Centre (ICRAF), Nairobi.

Kurosawa, R. \& Askins, R.A. 2003. Effects of habitat fragmentation on birds in deciduous forests. Japan Conservation Biology 17: 695-707.

Maro, P. 1974. Population and land resources in Northern Tanzania: the dynamics of change 1920-1970. PhD thesis, Faculty of the Graduate School, University of Minnesota.

Myers, N. 1992. The primary source: tropical forests and our future. W. W. Norton and Company, New York.

Moreau, R.E. 1944. Mt. Kilimanjaro and Mt. Kenya: Some comparisons with special reference to mammals and birds with a note on Mt. Meru (With bibliography of Kilimanjaro by C. Gillman). Tanganyika Notes and Records 14: 28-59.

Naidoo, R. 2004. Species richness and community composition of songbirds in a tropical forest agricultural landscape. Animal Conservation 7: 93-105.

Newmark, W.D., FOLEY, C.A.H., GRIMSHAW, J.M., CHAMBEGGA, O.A. \& RUTAZAA A.G. 1991. Local extinctions of large mammals within Kilimanjaro National Park and Forest Reserve and implications of increasing isolation and forest conversion. In: The Conservation of Mount Kilimanjaro, (ed.) W.D. Newmark. IUCN, Gland.

Nohr, H. \& Jorgensen, A.F. 1997. Mapping of biological diversity in Sahel by means of satellite image analyses and ornithological surveys. Biodiversity and Conservation 6: 545-566.

Odum, E. P. 1971. Fundamentals of ecology. Saunder Collage, Philadelphia.

O'kting'ati, A. \& Hussein, O. M. 1986. Agroforestry and the small farmer; A case study of Kilema and Kirua Vunjo in Kilimanjaro. The International Tree Crops Journal 3: 257-265.

O’kting'ati, A., Maghembe, J.A., Fernandes, E. C.M. \& Weaver, G.H. 1984. Plant species in the Kilimanjaro agroforestry system. Agroforestry Systems 2: 177-186.

Perfecto, I., Rice, R. A., Greenberg, R. \& Van Der Voort, M. 1996. Shade coffee: a disappearing refuge for biodiversity. Bioscience 46: 598-608.

Perfecto, I. \& Vandermeer, J. 2002.Quality of agroecological matrix in a tropical montane landscape: ants in coffee plantations in southern Mexico. Conservation Biology 16: 174-182.

Photomap International Ltd 2000. Aerial photos of Kirua Vunjo. Scale 1:40 000-1:60 000. Date: 16th of February 2000.

Ranjit Daniels, R. J., Joshi, N. V. \& Gadgil, M. 1992. On the relationship between bird and woody plant species diversity in the Uttara Kannada district of south India. Proceedings of National Academy of Science 89: 5311-5315.

Reitsma, R., Parrish, J.D. \& McLarney, W. 2001. The role of cacao plantations in maitaining forest avian diversity in southeastern Costa Rica. Agroforestry Systems 53: 185-193.

Robinson, R.A., Wilson, J.D. \& Crick, H.Q.P. 2001. The importance of arable habitat for farmland birds in grassland landscapes. Journal of Applied Ecology 38: 1059-1069.

Sala, O.E., Chapin III, F.S., Armesto, J.J., Berlow, E., Bloomfield, J., Dirzo R., Huber-Sanwald, E., Huenneke, L.F., Jakson, R.B., Kinzig, A., Leemans, R., Lodge, D.M., Mooney, H.A., Oesterheld, M., Leroy Poff, N., Sykes, M.T., Walker, B.H., Walker, M. \& Wall, D.H. 2000. Global biodiversity scenarios for the year 2100. Science 287: 1770-1774.

Shannon, C. E. \& Weaver, W. 1949. The mathematical theory of communication. University of Illinois Press, Urbana.

Sinclair, A.R.E., Mduma, S.A.R. \& Arcese, P. 2002. Protected areas as biodiversity benchmarks for human impact: agriculture and the Serengeti avifauna. Proceedings: Biological Sciences 1508: $2401-2405$. 
Soini, E. 2005 a. Changing livelihoods on the slopes of Mt. Kilimanjaro, Tanzania:

Challenges and opportunities in the Chagga homegarden system. Agroforestry Systems 2: 157-167.

Soini, E. 2005 b. Land use change patterns and livelihood dynamics on the slopes of Mt. Kilimanjaro, Tanzania. Agricultural Systems 85: 306-323.

Stevenson, T. \& Fanshawe, J. 2002. Field guide to the birds of East Africa: Kenya, Tanzania, Uganda, Rwanda and Burundi. T \& A D Poyser, London.

Thiollay, J.M. 1995. The role of traditional agroforests in the conservation of rain forest bird diversity in Sumatra. Conservation Biology 9: 335-353.

TNTmips 6.4 Manual 2000. Microimages Inc., Lincoln, Nebraska.

Tworek, S. 2002. Different bird strategies and their responses to habitat changes in an agricultural landscape. Ecological Research 17: 339-359.

Van Perlo, B. 1995. Birds of Eastern Africa. HarperCollinsPublishers Ltd., London.

Winter, M. \& Faabord J. 1999. Patterns of area sensitivity in grassland-nesting birds. Conservation Biology 13: $1424-1436$.

Wolff, A., Paul, J-P., Martin, J-L. \& Bretagnolle, V. 2001. The benefits of extensive agriculture to birds: the case of the little bustard. Journal of Applied Ecology 38: 963-975.

Zanette, L. 2000. Fragment size and the demography of an area-sensitive songbird. Journal of Animal Ecology 69: 458-470.

Zanette, L., Doyle, P. \& Tremont, S.M. 2000. Food shortage in small fragments: evidence from an areasensitive passerine. Ecology 81: 1654-1666.

Zimmerman, D.A., Turner, D.A. \& Pearson, D.J. 1999. Birds of Kenya \& Northern Tanzania. Christopher Helm Publishers Ltd., London.

Zongolo, S. A., Kiluvia S. \& Mghase, G. 2000a. Traditional irrigation assessment report, Moshi rural district. Traditional Irrigation and Environmental Development Organization, Moshi.

Zongolo, S. A., Kiluvia, S. \& Mghase, G. 2000b. Umbwe Onana PRA report. Traditional Irrigation and Environmental Development Organization, Moshi. 


\section{Working Paper Series}

1. Agroforestry in the drylands of eastern Africa: a call to action

2. Biodiversity conservation through agroforestry: managing tree species diversity within a network of community-based, nongovernmental, governmental and research organizations in western Kenya.

3. Invasion of prosopis juliflora and local livelihoods: Case study from the Lake Baringo area of Kenya

4. Leadership for change in Farmers Organizations: Training report: Ridar Hotel, Kampala, 29th March to 2nd April 2005

5. Domestication des espèces agroforestières au Sahel : situation actuelle et perspectives

6. Relevé des données de biodiversité ligneuse: Manuel du projet biodiversité des parcs agroforestiers au Sahel

7. Improved Land Management in the Lake Victoria Basin: TransVic Project's Draft Report

8. Livelihood capital, strategies and outcomes in the Taita hills of Kenya

9. Les espèces ligneuses et leurs usages: Les préférences des paysans dans le Cercle de Ségou, au Mali

10. La biodiversité des espèces ligneuses: Diversité arborée et unités de gestion du terroir dans le Cercle de Ségou, au Mali

11. Bird diversity and land use on the slopes of Mt. Kilimanjaro and the adjacent plains, Tanzania 


\section{Who we are}

The World Agroforestry Centre is the international leader in the science and practice of integrating 'working trees' on small farms and in rural landscapes. We have invigorated the ancient practice of growing trees on farms, using innovative science for development to transform lives and landscapes.

\section{Our vision}

Our Vision is an 'Agroforestry Transformation' in the developing world resulting in a massive increase in the use of working trees on working landscapes by smallholder rural households that helps ensure security in food, nutrition, income, health, shelter and energy and a regenerated environment.

\section{Our mission}

Our mission is to advance the science and practice of agroforestry to help realize an 'Agroforestry Transformation' throughout the developing world.

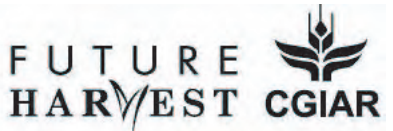

A Future Harvest Centre supported by the CGIAR

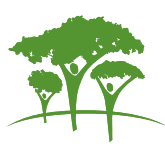

United Nations Avenue, Gigiri - PO Box 30677 - 00100 Nairobi, Kenya Tel: +254 207224000 or via USA +1 6508336645

Fax: +254207224001 or via USA +16508336646 www.worldagroforestry.org 